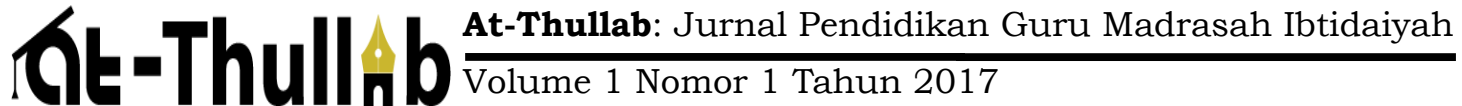

\section{MENAKAR KEMBALI KEBERADAAN PELAJARAN BAHASA INDONESIA SEBAGAI ILMU PENGETAHUAN DI SEKOLAH DASAR}

\author{
Minahul Mubin \\ Program Studi Pendidikan Guru Madrasah Ibtidaiyah \\ Universitas Islam Lamongan \\ e-mail : mubinbersabda01@gmail.com
}

\begin{abstract}
Indonesia language is an important part of education. Besides to be indonesia science, indonesia language becomes a long history. A long history of Indonesia language is started as nation's official and unitary languange. In 1928, as a burning spirit to grab independence, which has written in constitution 1945, from sequece of long history and pass the prosess of perfectingso that indonesia language becomes important thing as science today. In this case, to reinstate the position of Indonesia language to its fungtion and benefit, in order not to scrapped into this period that can make our children away from their identity. In fact, there will be polarization concerning with existence of Indonesia language, either using 2013 curriculum or not. Essentially, by virtue of, is Indonesia languange presented as Indonesia science or literature linguist which in practice 2013 curriculum in fact not giving art value in literature.The nature of Indonesia language is a science which must be given to students to educate how to communicate well. This communication can be done either oral or written, all of those is to understand and respond local situation, regional, national, and global. This is one of reason why Indonesia languange must be educated in all education level, especially in elemantry school because it is a foundation in all lessons.
\end{abstract}

Keywords: Mete Out, Indonesia Language, Science

\section{A. Pendahuluan}

Sebagai rujukan bahwa Bahasa Indonesia merupakan salah satu dari ribuan bahasa dunia, yang dimiliki oleh bangsa Indonesia sebagai alat komunikasi dan pengantar kehidupan masyarakat pada setiap bangsa pasti memiliki bahasa selain sebagai alat juga sebagai keilmuan. Sejarah juga telah menempatkan bahasa Indonesia menjadi pemersatu atas suku golongan bangsa sehingga bahasa indonesia memiliki kedudukan dan peran yang sangat tinggi sebagai ilmu pendidikan hal ini juga diperkuat sejak dicanangkan Kurikulum 2013 yang menempatkan bahasa Indonesia sebagai ilmu pengetahuan dan penerapan pembelajaran dengan konsep tematik terpadu, mata pelajaran Bahasa 
Indonesia tidak terpisah dari mata pelajaran lain. Bahasa Indonesia dipilih untuk mengintegrasikan ilmu pengetahuan alam (IPA) dan ilmu pengetahuan sosial (IPS). Integrasi tersebut membawa konsekuensi kewajiban menggunakan bahasa Indonesia sebagai sarana pencarian dan penemuan ilmu. Kementerian Pendidikan dan Kebudayaan (Kemdikbud) telah bertekad untuk membenahi kembali karakter bangsa yang mulai rusak dengan salah satunya menempatkan bahasa Indonesia sebagai bahasa ilmu.

Berdasarkan latar belakang tersebut, maka ini berisikan ulasan kritis tentang implementasi bahasa (sastra) Indonesia sebagai ilmu pengetahuan di sekolah dasar. Sekaligus menelusuri kemampuan bahasa Indonesia sebagai bahasa ilmu untuk mengembalikan karakter bangsa Indonesia. Ulasan yang juga perluuntuk diangkat yakni kemungkinan mereposisi ragam bahasa atau ragam sastra yang sejatinya tidak lepas dari bahasa Indonesia di Kurikulum 2013 sebagai kontribusi terbaik untuk membenahi karakter bangsa.

Bahasa Indonesia dalam Kurikulum 2013 telah dipersiapkan oleh Kementrian Pendidikan dan Kebudayaan untuk melaksanakan perintah konstitusi yakni sebagai bahasa sendiri di pendidikan Indonesia.Bahasa Indonesia menempati posisi sebagai bahasa pembawa wahana ilmu pengetahuan. Konsep tematik terpadu yang artinya memadukan berbagai mata pelajaran ke dalam sebuah tema, telah memfungsikan bahasa Indonesia sebagai pengantar ilmu pengetahuan antarmata pelajaran, penyalur yang menghubungkan satu tema dengan tema yang lain, dan pengembang tema pelajaran. Pendekatan pembelajaran dalam Kurikulum 2013 yang diterapkan adalah pendekatan scientific (ilmiah) (Caswo, 2013). Pendekatan ini memiliki teknik mengamati, menanya, menalar, menyaji, dan mencipta. Apabila menelisik lebih dalam, konsep pendekatan ini diturunkan melalui metode pembelajaran bahasa Indonesia yang berbasis teks. Tertulis dalam kata pengantar buku Bahasa Indonesia kurikulum 2013 oleh karena itu implementasi pembelajaran Bahasa Indonesia di Kurikulum 2013 adalah dengan berbasis teks (Caswo, 2013).

Pembelajaran yang berbasis teks dipilih sebagai implementasi bahasa Indonesia di sekolah yang diharapkan dapat lebih ramah terhadap bahasa daerah. Pembelajaran yang berbasis teks ini dipilih karenamampu menerobos sekat-sekat kebahasaan.Bahasa Indonesia diproses dalam pembelajaran di kelas unuk mengahasilkan penguasaan bahasa nasional.

Sebagaimana contoh yang telah terlaksana di Sekolah Dasar kelas I, siswa dituntut untuk mampu mendeskripsikan anggota tubuh yang mereka miliki, dengan rasa syukur kepada Tuhan. Hasil deskripsi tersebut dituturkan, "Alhamdulillah tubuhku lengkap.Ada kepala, badan, dua tangan, dan dua kaki.’'Deskripsi yang dituturkan oleh siswa digunakan supaya anak memperoleh pengalaman belajar secara konkret dengan penggunaan bahasa yang benar. 
Meskipun pemakaian bahasa Indonesia harus diterapkan di setiap mata pelajaran, untuk siswa kelas rendah (terutama kelas 1) Sekolah Dasar, pelaksanaannya dapat disandingkan dengan bahasa daerah atau bahasa ibu yang masih sering dipakai oleh penutur usia awal sekolah. Hal ini sering dilakukan oleh guru untuk membangun konteks pembelajaranyang akan disampaikan oleh guru. Salah satu contoh yang diterapkan yakni ketika siswaakan mendeskrpisikan anggota tubuhnya, guru dapat membangun konteks dengan mendeskripsikan anggota tubuh tersebut dengan penyebutan dalam bahasa daerah. Pembangunan konteks pelajaran itu berlangsung dengan sepenuhnyamelibatkan kearifan budaya lokal. Hal ini dimasudkan agar siswa tidak asing dengan pelajaran yang akan dilaksanakan di sekolah formal. Selain itu, dengan pemanfaatan kearifan budaya lokal yang salah satunya bahasa, program pelestarian dan penghargaan terhadap bahasa daerah juga menjadi lebih tinggi.Terkait dengan budaya di nusantara, penerapan ini pun berdampak pada tertampungnya keanekargaman budaya berbahasa daerah yang menjadi kekayaan bangsa Indonesua dapat tertampung dalam pelajaran di Sekolah Dasar.

Permasalahan bahasa Indonesia yang tidak dikuasai oleh siswa kelas rendah (kelas 1,2, dan 3) bukan permasalahan yang rumit sebab siswa kelas rendah tidak wajib memenuhi kemampuan ini dan boleh ditunda hingga siswa masuk kelas tinggi. Hal yang tidak boleh terjadi adalah hilangnya kosakata daerah dari diri siswa Sekolah Dasar. Berbagai fenomena tentang kedudukan bahasa Indonesia sebagai ilmu pengetahuan masih ditanggapi secara pro dan kontra. Pernyataan-pernyataan yang tersusun dalam wacana di atas adalah gambaran kekuatan bahasa Indonesia apabila ditempatkan sebagai ilmu pengetahuan dengan pembelajaran berbasis teks. Berikut inibeberapa kenyataan kondisi bahasa Indonesia di Sekolah Dasar yangdiamati secara kontra.

Perumusan kurikulum 2013 khususnya mata pelajaran bahasa Indonesia sepertinya tidak melibatkan sastrawan sebagai punggawa sastra Indonesia. Padahal, bahasa merupakan media untuk melahirkan sastra (Ismail, 2014). Tidak semua teori bahasa dapat disepadankan dengan praktik sastra. Seharusnya pembelajaran yang diusung oleh bahasa Indonesia di kurikulum ini adalah

penbelajaran bahasa yang berbasis (karya) sastra, artinya sastra menjadi bahan dalam pembelajaran bahasa Indonesia, bahkan bisa diterapkan untuk mata pelajaran yang lain. Materi pembelajaran bahasa Indonesia yang berbasis teks membuatsiswa jenuh karena setiap kali harus berhadapan dengan teks. Apalagi teks sastra yang sangat bermanfaat untuk mengembangkan karakter dan budi pekerti sangat minim didapatkan.Materi berbentuk teks ini pun masih harus banyak pembenahan karena sering kabur dan tumpang tindih.

Implementasi bahasa Indonesia di sekolah dasar dilakukan oleh guru dengan mengintegrasikan teks-teks dengan muatan mata pelajaran tertentu, terutama IPA dan 
IPS.Kenyataan yang terjadi di lapangan, materi pembelajaran lebih difokuskan pada pembelajaran tematik. Guru tidak bisa mengelak untuk lebih menekankan pada penyampaian isi teks daripada membedah bentuk teks. Sehingga siswa belum banyak mengetahui materi tentang berbagai bentuk teks yang ada di karangan-karangan yang beredardi masyarakat.Permasalahan ini bisa menjadi polemik jika siswa tadi akan menulis sebuah karangan atau cerita, sebab tidak ada konsep yang diajarkan oleh guru tentangberbagai bentuk teks. Salah satu pertanyaan yang masih sering muncul di masyarakat, terutama orang tua yang melakukan tugasnya sebagai pendamping belajar siswa di rumah yakni bagaimana membantu anak menguasai konsep-konsep dasar berbahasa yang ternyata masih muncul dalam soal ujian akhir sekolah, sementara guru tidak mengajarkannya di sekolah.

Konsep-konsep dasar berbahasa ini tidak diajarkan sebab bahasa Indonesia diterapkan (hanya) sebagai penghela ilmu pengetahuan. Hal lain yang masih menjadi bahan pertimbangan Kurikulum 2013 (apabila masih harus diterapkan) yakni bagaimana kemampuan berbahasa Indonesia guru kelas di Sekolah Dasar. Keberadaan kemampuan guru berbahasa Indonesia di dalam Kurikulum 2013 perlu mendapat perhatian lebih. Guru diharapkan dapat mengajarkan kemampuan berbahasa Indonesia yang baik dan benar. Dengan kemampuan guru yang telah mumpuni di bidang bahasa, diharapkan nantinya siswa akan memiliki kemampuan ilmu pengetahuan dan berbahasa Indonesia yang tinggi.

Solusi bagi Kurikulum 2013 khususnya dalam pembelajaran Bahasa Indonesia adalah guru harus berani bersikap bijak dalam menentukan teks. Teks yang telah disediakan oleh pemerintah melalui buku siswa telah cukup membantu, namun apabila konsep tentang teks yang tertulis belum tepat, guru harus mencari teks di luar bukusecara aktif agar nantinya tujuan pembelajaran dapat tercapai (Saleh, 2013).

\section{B. Hasil dan Pembahasan}

Pendekatan pembelajaran dapat diartikan sebagai titik tolak atau sudut pandang kita terhadap proses pembelajaran, yang merujuk pada pandangan tentang terjadinya suatu proses yang sifatnya masih sangat umum, di dalamnya mewadahi, menginsiprasi, menguatkan, dan melatari metode pembelajaran dengan cakupan teoretis tertentu. Dilihat dari pendekatannya, pembelajaran terdapat dua jenis pendekatan, yaitu: (1) pendekatan pembelajaran yang berorientasi atau berpusat pada siswa (student centered approach) dan (2) pendekatan pembelajaran yang berorientasi atau berpusat pada guru (teacher centered approach) (Prastowo, 2015).

Dalam pembelajaran Bahasa ada beberapa pendekatan di antaranya adalah:

1. Pendekatan Tujuan 
Pendekatan tujuan ini dilandasi oleh pemikiran bahwa dalam pembelajaran yang harus dipikirkan dan ditetapkan lebih dahulu ialah tujuan yang hendak dicapai. Dengan memperhatikan tujuan yang telah ditetapkan itu dapat ditentukan metode mana yang akan digunakan dan teknik pembelajaran yang bagaimana yang diterapkan agar tujuan pembelajaran tersebut dapat dicapai. Jadi proses pembelajaran ditentukan oleh tujuan yang telah ditetapkan, untuk mencapai tujuan itu sendiri.

Sejalan dengan itu, maka mata pelajaran apapun orientasinya pada pendekatan tujuan, demikian juga pada mata pelajaran bahasa Indonesia. Oleh karena orientasinya pada tujuan, maka pembelajarannya pun penekanannya pada tercapai tujuan.

Contoh berikut ini.

Untuk subtema menulis, tujuan pembelajaran yang ditetapkan ialah "Siswa mampu membuat karangan/cerita berdasarkan pengalaman atau informasi dari bacaan". Berdasarkan pada pendekatan tujuan, maka yang penting adalah pencapaian tujuan, yakni siswa memiliki kemampuan mengarang. Adapun bagaimana proses pembelajarannya, bagaimana metodeya, dan bagaimana teknik pembelajarannya tidak merupakan masalah yang penting (Caswo, 2013).

Demikian pula kalau misalnya diajarkan subtema struktur, dengan tujuan "siswa memiliki pemahaman mengenai bentuk-bentuk kata bahasa Indonesia" Tujuan tersebut dapat dicapai melalui pembelajaran morfologi bahasa Indonesia.Penerapan pendekatan tujuan ini sering dikaitkan dengan "cara belajar tuntas". Dengan "cara belajar tuntas", berarti suatu kegiatan pembelajaran dianggap berhasil, apabila sedikitnya $85 \%$ dari jumlah siswa mengikuti pelajaran itu mengusai minimal $75 \%$ dari bahan ajar yang diberikan oleh guru. Penentuan keberhasilan itu didasarkan hasil tes sumatif. Jika sekurang-kurangnya $85 \%$ dari jumlah siswa dapat mengerjakan atau dapat menjawab betul minimal $75 \%$ dari soal yang diberikan oleh guru maka pembelajaran dapat dianggap berhasil.

2. Pendekatan Tematik

Pendekatan tematik merupakan suatu strategi yang melibatkan beberapa mata pelajaran untuk memberikan pengalaman yang bermakna kepada pebelajar baik dari segi proses, waktu, segi kurikulum, dan segi aspek belajar-mengajar. Menurut Caswo. (2013) pembelajaran tematik hanya diajarkan pada siswa sekolah dasar kelas rendah (kelas I dan II), karena pada umumnya mereka masih melihat segala sesuatu sebagai satu keutuhan (holostik), perkembangan fisiknya tidak bisa dipisahkan dengan perkembangan mental, sosial, dan emosional ${ }^{6}$. Untuk itu, strategi pembelajaran tematik hendaknya, (1) bersahabat, menyenangkan, tetapi tetap bermakna bagi anak, (2) dalam menanamkan konsep atau pengetahuan dan 
keterampilan, anak tidak harus didrill, tetapi ia belajar melalui pengalaman langsung dan menghubungkannya dengan konsep lain yang sudah dipahami.

Bentuk pembelajaran ini dikenal dengan pembelajaran terpadu, dan pembelajaran sesuai dengan kebutuhan dan perkembangan siswa. Sesuai dengan perkembangan fisik dan mental siswa kelas I dan II, pembelajaran pada tahap ini mempunyai ciri-ciri sebagai berikut :

a. Berpusat pada siswa

b. Memberikan pengalaman langsung pada anak

c. Pemisahan mata pelajaran tidak begitu jelas

d. Menyajikan konsep dari beberapa mata pelajaran

e. Bersifat fleksibel

f. Hasil belajar dapat berkembang sesuai dengan minat dan kebutuhan siswa

Disamping itu, pembelajaran tematis memiliki beberapa kekuatan yakni :

a. Pengalaman dan kegiatan belajar yang relevan dengan tingkat perkembangan dan kebutuhan anak

b. Menyenangkan karena bertolak dari minat dan kebutuhan anak

c. Hasil belajar akan bertahan lebih lama karena lebih terkesan dan bermakna

d. Mengembangkan berpikir anak sesuai dengan permasalahan yang dihadapi

e. Menumbuhkan keterampilan sosial dalam bekerja sama, toleransi, komunikasi, dan tangap terhadap gagasan.

\section{Pendekatan Komunikatif}

Pendekatan komunikatif merupakan pendekatan yang dilandasi oleh pemikiran bahwa kemampuan menggunakan bahasa dalam berkomunikasi merupakan tujuan yang harus dicapai dalam pembelajaran bahasa. Tampak bahwa bahasa tidak hanya dipandang sebagai seperangkat kaidah, tetapi lebih luas lagi, yakni sarana berkomunikasi. Ini berarti, bahasa ditempatkan sesuai dengan fungsinya, yakni fungsi komunikasi.

Hal ini menimbulkan kesadaran bahwa pembelajaran bahasa, tidak cukup dengan memberikan kepada siswa bagaimana bentuk-bentuk bahasa itu, tetapi siswa harus mampu mengembangkan cara-cara menerapkan bentuk-bentuk itu sesuai dengan fungsi bahasa sebagai sarana komunikasi dalam situasi dan waktu yang tepat.

Berdasarkan uraian diatas, maka penerapan pendekatan berkomunikatif bertujuan agar siswa mampu berkomunikasi dan mampu menggunakan bahasa secara baik, benar, dan secara nyata dan wajar, serta dapat digunakan untuk berbagai tujuan dan keadaan. Di samping itu kemampuan komunikasi menuntut adanya kemampuan gramatikal, kemampuan sosiolinguistik, kemampuan wacana, dan kemampuan strategi. Dalam proses pembelajaran, guru hanya berfungsi sebagai komunikator, 
fasilitator, dan motivator. Sehubungan dengan itu, yang menjadi acuan adalah kebutuhan siswa untuk dapat berkomunikasi dalam situasi yang sebenarnya. Oleh karena itu, untuk memenuhi atau meningkatkan keterampilan menggunakan bahasa sebagai alat komunikasi itu, pembelajaran bahasa yang paling tepat adalah menggunakan pendekatan komunikatif.

Untuk dapat merancang materi pengajaran yang mengacu pada pendekatan komunikatif (Saleh, 2013) guru harus memperhatikan hal-hal sebagai berikut :

a. Tujuan pembelajaran didalam kelas difokuskan pada semua komponen dari kemampuan berkomunikasi

b. Teknik dalam pembelajaran bahasa dirancang untuk melibatkan siswa dalam penggunaan bahasa yang pragmatis, autentik, fungsional dan bermakna,

c. Kelancaran dan ketepatan berbahasa yang dapat melandasi teknik-teknik komunikatif,

d. Siswa pada akhirnya harus menggunakan bahasa, baik secara produktif maupun reseptif.

Untuk mendukung pendekatan ini harus mengetahu metode yakni :

a. Ketahuilah apa yang anda kerjakan

b. Keseluruhan lebih penting dari bagian-bagiannya

c. Proses sama pentingnya dengan bentuk bahasa yang dihasilkan

d. Untuk mempelajari sesuatu, kerjakanlah hal itu

e. Kekeliruan bukanlah suatu kesalahan

Pada dasarnya, bahasa dipergunakan untuk berkomunikasi, untuk menyampaikan dan menerima pesan dari orang lain, dari penulis kepada pembaca, , dari pembicara kepada pendengar, pembaca menerima dari penulis, pendengar menerima dari pembicara. Pendekatan ini bertujuan mengaktifkan siswa agar memiliki kemampuan berkomunikasi baik secara lisan maupun tulisan.

Komunikasi terjadi oleh adanya berbagai faktor. Faktor yang mendukung terjadinya komunikasi adalah :

a. Siapa dengan siapa yang berkomunikasi?

b. Untuk tujuan apa terjadinya komunikasi?

c. Dalam situasi apa berkomunikasi?

d. Dalam konteks apa?

e. Melalui jalur apa: tulisan, lisan?

f. Dengan media apa: telepon, surat telegram.surat kabar, buku?

g. Dalam peristiwa apa: bercakap-cakap, ceramah, upacara, lamaran pekerjaan, pernyataan emosi, laporan.

Pada bagian terdahulu sudah dikemukakan bahwa pandangan tentang bahasa dan pembelajaran bahasa selalu mengalami perubahan, sejalan dengan 
perkembangan pola pikir masyarakat. Dalam kaitannya dengan pembelajaran bahasa Indonesia, akhir-akhir ini sedang digalakkan penerapan pendekatan komunikatif dan pendekatan terpadu.

Alternatif lain yang dapat dipakai sebagai acuan penerapan pendekatan komunikatif dalam pembelajaran bahasa pada siswa diberi latihan dengan teknik sebagai berikut.

a. Memberikan Informasi Secara Terbatas

1) Mengidentifikasi gambar. Dua orang siswa ditugasi melakukan percakapan tentang gambar yang disediakan oleh guru. Pertanyaan dapat mengenai warna, jumlah, bentuk, dan sebagainya.

2) Menemukan informasi yang ditiadakan. Guru memberikan informasi tentang gambar, tetapi ada bagian-bagian yang sengaja ditiadakan. Siswa siswa ditugasi atau menemukan bagian-bagian yang tidak ada itu. Kemudian A mengajukan pertanyaan-pertanyaan kepada $\mathrm{B}$, sehingga $\mathrm{A}$ dapat mengetahui gambar yang mana yang tidak ada pada gambar milik B.

b. Memberikan informasi tanpa dibatasi (bebas tak terbatas)

1) Mengomunikasikan contoh dan gambar. Siswa A membawa sebuah model bentuk-bentuk yang diatur/disusun ke dalam (menjadi) sebuah contoh, Siswa B juga membawa bentuk-bentuk yang sama. Mereka A dan B, harus saling memberikan informasi sehingga $\mathrm{B}$ dapat mengetahui contoh yang ada pada $\mathrm{A}$ dengan setepat-tepatnya.

2) Menemukan perbedaan. Siswa A dan B masing-masing mempunyai sebuah gambar yang sama, kecuali beberapa bagian . Para siswa harus mendiskusikan gambar tersebut sehingga menemukan perbedaanya.

3) Menyusun kembali bagian-bagian cerita. Sebuah gambar cerita (tanpa dialog) dipotong-potong. Setiap anggota kelompok memegang satu bagian tanpa mengetahui bagian gambar yang dipegang oleh yang lain; kelompok itu harus menentukan urutan aslinya, dan menyusun kembali cerita.

4) Mengumpulkan informasi untuk memecahkan masalah. Siswa mempunyai rencana akan mangunjungi sebuah kota yang menarik. B mempunyai daftar/jadwal bus. Mereka harus merencanakan perjalanan yang akan dilakukan yang memungkinkan mereka untuk mengunjungi beberapa tempat (misalnya 5 tempat) dalam satu hari, dan menggunakan waktu sekurang-kurangnya setengah jam untuk setiap tempat. Siswa harus memilih tempat yang paling menarik bagi mereka.

5) Menyusun informasi. Siswa diminta membayangkan bahwa mereka akan mengadakan "camping" (berkemah) selama tiga hari. Tiap anggota hanya boleh membawa barang kira-kira seberat tiga kg. Kelompok itu harus 
menentukan apa saja yang mereka bawa, dengan melihat daftar barang yang patut dibawa, yang diberikan oleh guru, dan mempersiapkan pembekalan apabila mereka ditentang oleh kelompok lain.

Latihan-latihan tersebut merupakan latihan penggunaan bahasa dalam aktivitas berkomunikasi yang bersifat fungsional di dalam kelas. Di samping itu, juga terdapat tipe aktivitas berkomunikatif yang lain, yakni aktivitas interaksi sosial, yang diberikan kepada siswa yang lain berupa :

a. Kelas sebagai konteks sosial. Contoh :Percakapan atau diskusi

b. Simulasi dan bermain peran. Contoh :

1) Siswa diminta membayangkan dirinya ada dalam situasi yang dapat terjadi di luar kelas. Ini dapat saja berupa kejadian yang sederhana, misalnya bertemu seorang teman di jalan; tetapi dapat pula kejadian yang bersifat kompleks, negosiasi di dalam bisnis.

2) Mereka (siswa) diminta memilih peran tertentu dalam suatu situasi. Dalam beberapa kasus, mungkin mereka berlaku sebagai dirinya sendiri, tetapi dalam beberapa kasus-kasus lain mungkin mereka memperagakan sesuatu, di dalam simulasi.

3) Mereka diminta berbuat seperti kalau situasi ini benar-benar terjadi, sesuai dengan peran mereka masing-masing. Permainan peran tidak selalu dalam bentuk akting, tetapi dapat juga dalam bentuk debat, atau improvisasi.

Beberapa hal penting yang harus diperhatikan oleh guru dalam pembelajaran bahasa dengan menggunakan pendekatan komunikatif, yaitu :

a. Konsep komunikasi (siapa, apa, dimana, dan bagaimana) harus diperhatikan.

b. Pelatihan kepekaan siswa untuk memilih ragam bahasa yang tepat sesuai dengan situasi komunikasi perlu diperhatikan, karena selama ini ada salah tafsir bahwa penggunaaan bahasa Indonesia dengan baik dan benar diartikan sebagai penggunaan bahasa Indonesia baku.

c. Untuk pelatihan bermacam komunikasi, pelatihan bermain peran atau drama sangat baik dan menyenangkan siswa.

d. Dengan demikian, acuan pokok setiap unit pembelajaran adalah fungsi bahasa, bukan tata bahasa. Dengan kata lain, tata bahasa disajikan bukan sebagai tujuan akhir, tetapi sarana untuk mencapai maksud melaksanakan komunikasi.

Mencermati kompetensi kebutuhan siswa untuk dapat ber-komunikasi dalam situasi yang sebenarnya, bahwa pembelajaran bahasa sebagai alat komunikasi akan menarik minat siswa karena didesak oleh kebutuhannya untuk berkomunikasi dengan orang lain. Oleh karena itu, untuk memenuhi atau meningkatkan keterampilan 
menggunakan bahasa sebagai alat komunikasi itu, pengajaran bahasa yang paling tepat adalah menggunakan pendekatan komunikatif.

4. Pendekatan Struktural

Pendekatan struktural merupakan salah satu pendekatan dalam pembelajaran bahasa, yang dilandasi oleh asumsi yang menganggap bahasa sebagai perangkat kaidah. Atas dasar anggapan tersebut, maka pembelajaran bahasa harus mengutamakan penguasaan kaidah-kaidah bahasa atau tata bahasa. Pembelajaran bahasa dititik beratkan pada pengetahuan tentang struktur bahasa yang tercangkup dalam fonologi, morfologi, dan sintaksis. Dalam hal ini pengetahuan tentang polapola kalimat, pola-pola gabungan kata, pola kata, dan suku kata menjadi sangat penting.

Adapun perbedaan antara pendekatan structural dan komunikatif, yaitu :

\begin{tabular}{|c|c|}
\hline Pendekatan Struktural & Pendekatan Komunikatif \\
\hline $\begin{array}{l}\text { 1. Mementingkan struktur dari pada } \\
\text { makna } \\
\text { 2. Item bahasa tidak harus kontekstual } \\
\text { 3. Belajar bahasa adalah belajar } \\
\text { struktur bunyi atau kata } \\
\text { 4. Penguasaan bahasa yang diharapkan } \\
\text { 5. Drill adalah teknik utama } \\
\text { 6. Pengucapan seperti penutur asli } \\
\text { yang diharapkan } \\
\text { 7. Kegiatan komunikasi hanya terjadi } \\
\text { setelah proses panjang dari pelatihan } \\
\text { terus-menerus } \\
\text { 8. Membaca dan menulis diberikan } \\
\text { sedikit demi sedikit sampai dikuasai } \\
\text { 1. Kemampuan linguistik adalah tujuan } \\
\text { yang diharapkan } \\
\text { 2. Ragam bahasa dikenalkan tetapi } \\
\text { tidak ditentukan } \\
\text { 3. Urutan unit ditentukan semata-mata } \\
\text { oleh kompleksitas bahasa } \\
\text { 4. Makna adalah yang utama }\end{array}$ & $\begin{array}{l}\text { 1. Membaca dan menulis dapat } \\
\text { dimulai dari hari pertama jika } \\
\text { dikehendaki } \\
\text { 2. Kemampuan komunikasi adalah } \\
\text { tujuan yang diharapkan } \\
\text { 3. Variasi bahasa adalah konsep utama } \\
\text { dalam materi dan metodelogi } \\
\text { 4. Urutan ditentukan oleh } \\
\text { pertimbangan isi atau makna yang } \\
\text { menjadi perhatian utama }\end{array}$ \\
\hline
\end{tabular}

5. Pendekatan Keterampilan Proses

Pendekatan keterampilan didasarkan pada asumsi bahwa belajar merupakan proses mengubah tingkah laku, baik kognitif, afektif, maupun psikomotor. Dalam 
kegiatan belajar perwujudan dari pendekatan keterampilan proses adalah CBSA. CBSA merupakan pendekatan dalam proses belajar-mengajar yang mengutamakan aktivitas mental psikologis siswa, siswa berperan sebagai subjek dalam kegiatan pembelajaran sedangkan guru berfungsi sebagai pembimbing, pengamat, dan memberikan bantuan apabila diperlukan.

Adapun penerapan konsep CBSA dalam pengajaran menulis akan diuraikan dalam kegiatan siswa, kegiatan guru, iklim belajar, dan program belajar.

a. Kegiatan Siswa

Sejalan dengan penerapan konsep keterampilan proses, maka dalam kegiatan belajar para siswa diberikan kesempatan untuk mengamati objek yang akan ditulinya sesuai dengan tema atau topik karangan. Misalnya apabila terdapat kata-kata yang tidak dimengerti, para siswa dapat mencari dalam kamus yang telah disediakan oleh guru atau kalau masih belum jelas siswa dapat menanyakan kepada teman, bahkan kepada guru bila perlu.

b. Kegiatan Guru

Guru adalah teman belajar siswa yang harus mampu memberikan dorongan, bimbingan, dan arahan kepada para siswa. Guru berperan sebagai fasilitator, artinya menyediakan fasilitas yang diperlukan oleh siswa demi kelancaran kegiatan belajar.

Dalam kegiatan belajar menulis, guru hendaknya dapat menciptaka iklim belajar yang kondusif untuk melakukan kegiatan belajar menulis. Misalnya, siswa diberikan pokok-pokok kalimat yang harus dikembangkan dengan menggunakan pilihan kata yang disediakan. Seperti contoh berikut ini :

1) Lengkpilah kalimat berikut dengan kata-kata yang sesuai atau tepat!

a. kebun

Pak tani menanam jagung di ... $\quad$ b. kantor

Ayah bekerja di ...

c. dapur

Anak-anak ditugasi untuk melengkapi kalimat tersebut. Hasilnya sebagai berikut .

Ibu menanak nasi di dapur

Pak tani menanam jagung di kebun

Ayah bekerja di kantor

2) Susunlah huruf-huruf ini sehingga menjadi sebuah kata!

$\begin{array}{lll}\text { a-s-w-i-s } & \text { hasilnya } & \text { siswa } \\ \text { a-m-u-e-s } & \text { hasilnya } & \text { semua } \\ \text { h-k-o-l-a-s-e } & \text { hasilnya } & \text { sekolah }\end{array}$

Penerapan Pendekatan Terpadu 
Dalam pembelajaran bahasa Indonesia dikelas-kelas rendah, keterampilan tersebut dapat diwujudkan sebagai berikut :

1. Ketika guru mengajarkan menulis kalimat atau kata-kata, sekaligus guru mengajarkan bagaimana melafalkannya (mengucapkannya) dengan tepat. Dalam hal ini guru mengkaitkan kegiatan membaca dan pemahaman tentang lafal atau ucapan yang tercakup dalam tata bunyi.

2. Ketika guru mengajarkan menulis kalimat atau kata-kata, guru sekaligus juga mengajarkan bagaimana membacanya, melafalkannya, dan bagaimana ejaannya. dalam hal ini, kecuali guru mengaitkan membaca dan lafal, guru juga mengaitkannya dengan fonem, walaupun istilah tersebut tidak dinyatakan kepada siswa . Hal ini dilihat misalnya pada waktu siswa harus menuliskan kata-kata seperti, mama, mana, mata, yang maknanya berbeda-beda karena perbedaan pada $/ \mathrm{m} / \mathrm{n} /$,dan $/ \mathrm{t} /$.

3. Pada waktu guru mengajarkan membaca kalimat, guru sekaligus mengajarkan bagaimana intonasinya, pelafalannya, tanda baca yang ada dalam bacaan. dan bagaimana membaca kalimat itu dengan memperhatikan tanda-tanda baca yang digunakan. Disamping itu, guru berkesempatan menambah kosa kata siswa dan pada waktu guru memberikan contoh membaca atau salah seorang siswa membaca, tentu saja siswa yang lain harus menyimak.

4. Pada saat guru mengajarkan menulis kalimat, guru sekaligus mengajarkan ejaan bagaimana cara menggunakan tanda baca dalam kalimat., seperti titik, koma, dan tanda tanya. Disamping itu, siswa juga diminta membaca kalimat-kalimat yang telah mereka buat, siswa yang sedang tidak membaca akan mendengarkan dengan baik atau menyimak. Jika demikian telah ada pemaduan antara menulis, membaca dan menyimak tetapi dalam hal ini tekanannya pada keterampilan menulis.

5. Pada waktu guru mengajarkan keterampilan berbicara sekaligus guru mengajarkan intonasi, lafal, dan menyimak. Mungkin setelah salah satu siswa bercerita, siswa yang lain diminta mengemukakan isi cerita itu secara singkat. Dengan demikian, pada waktu salah seorang siswa bercerita, temannya benar-benar menyimak.

6. Keterampilan menyimak dapat dipadukan dengan keterampilan berbicara maupun keterampilan menulis. Pada pembelajaran menyimak ini, dapat juga guru sengaja menggunakan atau menyelipkan kata-kata baru bagi siswa, sehingga menambah pembendaharaan kata mereka. Jika demikian, berarti guru telah memadukan menyimak, berbicara, menulis dan pembendaharaan kosa kata siswa.

7. Pada waktu guru mengajarkan kata-kata baru, guru harus selalu ingat bahwa katakata tersebut harus masuk dalam kalimat atau dalam bacaan (di dalam konteks). Jadi dalam hal ini, guru mengajarkan kata baru sekaligus mengajarkan bagaimana penggunaannya didalam kalimat. Dalam hal ini ada pemaduan antara kosa kata keterampilan berbahasa dan struktur. 
8. Pemaduan dengan bidang-bidang studi lain seperti IPA, IPS, dan matematika dilakukan melalui penyajian tema dan materi berkaitan dengan bidang studi tersebut. Di kelas-kelas yang lebih tinggi, pembelajaran aspek-aspek keterampilan berbahasa diberikan secara terpadu. Misalnya:

a. Menyimak dan berbicara.

Contoh Guru menceritakan sebuah peristiwa, siswa menyimak cerita tersebut. Setelah selesai, siswa diberi waktu sejenak dan kemudian seorang siswa diminta menceritakan kembali isi cerita tersebut dengan bahasa (kalimat-kalimat) siswa sendiri secara singkat.

Dalam hal ini, yang diutamakan adalah kemampuan siswa memahami apa yang mereka simak dan kemampuan mengemukakan pikirannya. Karena yang mendapat kesempatan berbicara hanya beberapa siswa, yang lain diberi kesempatan untuk menyatakan pendapatnya mengenai dialog yang dilakukan oleh teman-temannya yang mendapat kesempatan di depan kelas. Dengan cara-cara tersebut, guru memadukan, menyimak dan berbicara.

b. Menyimak dan menulis

Guru membacakan dan memperdengarkan rekaman drama atau sebuah cerpen, kemudian siswa menyimak. Beberapa drama/cerpen itu dibaca/diperdengarkan, tergantung pada tingkat kesukaran drama/cerpen tersebut. Setelah selesai, siswa diberi waktu untuk menanyakan yang tidak mereka mengerti. Sesudah itu mereka diberikan waktu untuk menjawab pertanyaanpertanyaan guru tentang drama/ cerpen itu., atau diminta menuliskan isi cerpen/drama secara ringkas dengan kalimat mereka sendiri.Dapat juga diminta siswa mendengarkan radio atau televisi pada acara tertentu, dan diminta membuat laporan hasil simakannya secara tertulis. Dalam hal ini guru harus jeli, memiliki acara- acara yang memungkinkan dilaksanakannya tugas tersebut oleh siswa. Dengan cara-cara diatas guru memadukan pelajaran menyimak dan menulis. Cara yang lain masih cukup banyak.

c. Membaca dan menyimak

Contoh Siswa diberi tugas membacakan suatu wacana. Dalam hal ini ketentuan-ketentuan membaca untuk orang lain harus dipahami oleh siswa. Siswa yang lain menyimak. Setelah itu siswa diberikan waktu untuk berfikir, kemudian tugas selanjutnya, mungkin siswa diminta untuk menceritakan isi yang disimak secara lisan atau mungkin tertulis. dalam hal ini, agar yang mendapat giliran membaca tidak sedikit, naskah yang dibaca sebaiknya naskah-naskah yang pendek, seperti informasi singkat, perintah,dan sebaginya. Dengan cara-cara diatas guru memadukan membaca dengan menyimak.

d. Membaca dan menulis 
Contoh Guru memberikan tugas kepada siswa untuk membaca cerita dan tulisan-tulisan yang lain diluar kelas, dan meminta kepada mereka untuk menuliskan ringkasan hasil bacaan masing-masing. Setelah mereka menuliskan hasil ringkasannya tersebut, guru dapat meminta kepada siswa untuk mengumpulkan saja hasil mereka, atau dapat juga sebelum mereka mengumpulkan, beberapa siswa diberi giliran untuk membacakan atau mengemukakan hasil mereka masing-masing. Dengan cara seperti itu terjadi pemaduan antara membaca, menulis dan berbicara.

e. Menulis dan bercerita

Contoh Guru memberikan tugas kepada siswa untuk membuat karangan di luar kelas. Pada waktu yang telah ditentukan, siswa menceritakan isi karangannya, sebelum karangan itu dikumpulkan. Siswa dibagi dalam kelompok-kelompok kecil.masing-masing kelompok beranggotakan tiga atau empat orang. Tiap kelompok diberi tugas merencanakan dan menuliskan sebuah adegan yang dapat diperankan. Pada jam yang telah disepakati bersama, sebelum naskah diserahkan kepada guru, tiap kelompok diminta memperagakan apa yang telah mereka rencanakan dan mereka tulis itu.

\section{Pendekatan Pengalaman Berbahasa (PPB)}

Pendekatan pengalaman berbahasa dalam bidang membaca dapat dibatasi sebagai pengajaran membaca dengan menggunakan wacana yang dikembangkan bersama-sama dengan anak-anak. Dalam PPB guru merangsang anak-anak untuk berpikir tentang pengalaman masing-masing. Guru memberikan dorongan kepada anak-anak untuk bercerita. Rekaman guru yang menggunakan huruf-huruf yang jelas itu harus dilakukan di depan anak-anak supaya anak-anak sadar bahwa bahasa lisan itu bisa diubah menjadi bahasa tulisan.

Berikut adalah penjelasan mengenai langkah-langkah PPB, keunggulan PPB, dan kelemahan PPB.

\section{Langkah-langkah PPB}

Pertama, guru mengembangkan wacana bersama siswa, guru menyuruh siswa memikirkan hal-hal yang merupakan kesukaannnya. Guru memotivasi anak itu dengan jalan berkata bahwa dia ingin tahu kesenangannya.

Kedua, guru berupaya untuk mendengarkan sebaik-baiknya dan mengarahkan percakapan yang berlangsung antara murid-muridnya. Sepintas lalu, upaya yang harus dilakukan guru itu mudah, namun dalam suatu kelompok yang terdiri dari banyak murid, pekerjaan mengarahkan pembicaraan mereka supaya setiap anak mendapat giliran untuk mengemukakan pendapatnya itu. 
Ketiga, menuliskan hal-hal yang disampaikan oleh murid. Biasanya guru memberikan petunjuk kepada murid supaya yang dikemukakan itu berupa sebuah cerita. Dia memberi contoh cara memulai sebuah cerita, atau yang lebih baik ialah meinta saran murid-muridnya tentang cara yang mereka sukai. Semua saran harus diperhatikan dan murid disuruh memilih yang terbaik.

Keempat, guru mendengar bacaan muridnya. Guru menyuruh muridnya membaca wacana yang merupakan hasil rekamannya itu. Jika dia bekerja dengan seorang siswa, maka dia harus memperhatikan kata-kata yang dikenal muridnya dan kata-kata mana yang tidak dikenalnya. Guru mencatat kata-kata yang diucapkan oleh muridnya itu yang tidak ada dalam wacana.

Kelima, penggunaan wacana dalam pembelajaran membaca. Guru harus memanfaatkan pengetahuan yang diperolehnya dari bacaan murid-muridnya. Kalau guru tahu bahwa siswanya tidak dapat membaca kata tertentu yang ada dalam wacana yang digunakan, dia harus mengajarkan dengan cara memisahkan kata tertentu dari wacana.

\section{Keunggulan PPB}

1. Sifat PPB dapat meningkatkan minat baca anak,

2. Untuk menjebatani ke dunia anak-anak dalam upaya mengenali lebih baik keperluan, keinginan dan minat anak,

3. Tidak memerlukan biaya yang banyak, cukup dengan kertas, papan tulis, pensil dan kapur.

\section{Kelemahan PPB}

1. Sifat PPB yang hanya digunakan pada pembelajaran membaca tingkat awal;

2. PPB menuntut waktu yang lebih banyak dibandingkan pendekatan-pendekatan lain; PPB tidak hanya menyajikan kata-kata yang mana yang harus diperkenalkan kepada murid dan keterampilan apa yang harus diajarkan.

\section{Contoh Pembelajaran Tematik}

Implementasi bahasa Indonesia sebagai penghela ilmu pengetahuandi sekolah dasar masih menimbulkan polemik Polemik ini dilihat dari dua pandangan, yakni pandangan yang pro dengan kebijakan bahasa sebagai penghela ilmu pengetahuan dengan penerapan pembelajaran bahasa Indonesia yang berbasis teks dan kontra terhadap kebijakan ini. Pandangan bahwa bahasa Indonesia menjadi mulia pada Kurikulum 2013 karena dijadikan sebagai ilmu pengetahuan sangat menguat dengan berbagai bukti bahwa dengan pemakaian bahasa Indonesia sebagai satu-satunya pengantar belajar siswa dengan cara pendekatan tematik terpadu di Kurikulum 2013. 
(Caswo, 2013) maka bahasa Indonesia dapat menjadi bahasa pendidikan. Sebagaimana pepatah "sekali mendayung-dua tiga pulau terlampaui" atau "sambil menyelam minum air", maka ketika guru menyampaikan materi teks yang berbahasa Indonesia, saat itu juga materi IPA dan IPS juga tersampaikan.

Perbedaan tanggapan tentang implementasi bahasa Indonesia terjadi karena bahasa Indonesia tidak membawa serta sastra, padahal sastra sangat berperan dalam pembentukan karakter bangsa.Selain itu, kemampuan berbahasa Indonesia guru juga menjadi salah satu hal yang harus menjadi pertimbangan apabila bahasa Indonesia tetap menjadi penghela ilmu pengetahuan yang diterapkan dengan pendekatan tematik integratif dan berbasis teks.

\section{Simpulan}

Pembelajaran bahasa Indonesia memiliki fungsi yang sangat penting sebagai alat kemunikasi dan sebagai identitas bangsa, juga mempunyai peranan di dalam membentuk kebiasaan, sikap, serta kemampuan siswa untuk tahap perkembangan selanjutnya.Selain itu, pembelajaran harus dapat membantu siswa dalam pengembangan kemampuan berbahasa di lingkungannya, bukan hanya untuk berkomunikasi, namun juga untuk menyerap berbagai nilai serta pengetahuan yang dipelajarinya.Melalui bahasa, siswa mampu mempelajari nilai-nilai seni dan budaya, nilai-nilai moral, nilainilai agama, serta nilai-nilai sosial yang berlaku di masyarakat, melalui bahasa, siswa juga mampu mempelajari berbagai cabang ilmu.

Bahasa dalam dunia pendidikan mempunyai peran setrategis dalam keilmuan sosial dan emosional karena bahasa Indonesia merupakan bahasa pengantar pendidikan di semua jenjang pendidikan mulai dari yang paling pendidikan dasar, menengah hingga pendidikan tinggi. Selain itu juga Bahasa Indonesia bisa dijadikan tolak ukur untuk upaya meningkatkan mutu pendidikan dasar khususnya sekolah dasar (SD) yaitu penguasaan ilmu pengetahuan dan teknologi karena bahasa Indonesia merupakan sarana berpikir untuk menumbuh kembangkan cara berpikir secara logis, sistematis, kritis, dan terstruktur.

Ada beberapa penyebab kurang berhasilnya pembelajaran bahasa indonesia di sekolah dasar dikarenakan sebagian pendidik masih menggunakan pola prndidikan tidak terpadu dari empat dasar dalam ilmu bahasa (keterampilan menulis, membaca, menyimak, dan berbicara) ini berdiri sendiri-sendiri, bahkan dianggap sebagai ilmu tersendiri. Pemikiran mengenai peningkatan keterampilan siswa dengan pendekatan pembelajaran terpadu dalam pembelajaran bahasa Indonesia merupakan hal yang penting untuk dilakukan. Dengan demikian, penerapan pembelajaran terpadu sangat penting untuk peningkatan keterampilan siswa dalam bidang bahasa Indonesia pada siswa di SD kelas rendah maupun kelas tinggi. 
Salah satu keberhasilan suatu pembelajaran ditentukan oleh penerapan yang digunakan oleh guru dalam kegiatan pembelajaran tersebut.Karena semua mengacu pada asumsi yang saling keterkaitan baik secara teoritis maupun metode. Asumsi tentang bahasa bermacam-macam, asumsi menganggap bahasa sebagai kebiasaan, atau bahasa sebagai suatu sistem komunikasi yang pada dasarnya dilisankan ,serta bahasa sebagai seperangkat kaidah.

Bahasa Indonesia di sekolah dasar (SD) dapat diartikan sebagai tolak ukur atau sudut pandang kita terhadap proses pembelajaran bahasa Indonesia sejak dini, yang merujuk pada pandangan tentang terjadinya suatu proses yang sifatnya masih sangat umum, di dalamnya mewadahi, menginsiprasi, menguatkan, dan melatari metode pembelajaran dengan cakupan teoretis tertentu yang bertujuanuntuk pendidikan komunikatif, dan pendidikan tematik.

\section{Daftar Rujukan}

Caswo. (2013). Kurikulum 2013 dan Peran Bahasa Indonesia.

Ismail, M. (2014). Pembelajaran (Bahasa) Sastra dalam Kurikulum 2013.

Prastowo, A. (2015). Menyusun Rencana Pelaksanaan Pembelajaran (RPP) Tematik

Terpadu Implementasi Kurikulum 2013 untuk SD/MI (Prenadamedia, Ed.). Jakarta.

Saleh, R. (2013). Bahasa Indonesia dalam Kurikulum 2013. 